\title{
The Comic Kaleidoscope: Untying the Comic Knots of Bhranti Bilas and the Comedy of Errors beyond Cultural and Generic Boundaries
}

\author{
Ritushree Sengupta
}

\begin{abstract}
$\underline{\text { Abstract }}$
Macaulay's Education act of 1835 was contrived to create a section of Brown Sahibs to assist the British Empire born out of a culture in which Shakespeare was invincible. Since the foundation of the Calcutta Theatre in 1775, Bengal saw the rise of "bhadraloks" appreciating Shakespearean works and giving them their share of recognition. It further resulted into a creation of a number of indigenous texts which quite powerfully posited the Shakespearean texts into totally different socio-cultural contexts, at times remaining faithful to the plot while at times craftily diverting from it. One of such texts is Ishwar Chandra Vidyasagar's Bhranti Bilas (1869), which has a plot very close to that of Shakespeare's The Comedy of Errors and one might accurately consider it to be the first "translation" of Shakespeare into Bengali. Vidyasagar's text finely deals with the plot keeping it almost the same but transforms its dramatic form into a story. Interestingly, this text is further adapted into a play in 1888 and into a commercial film in 1963 directed by Manu Sen.
\end{abstract}

The politics involved not only in the translation but also in the transformation of the genre has to be located within and beyond the two different literary texts and the film adaptation as well. This paper shall attempt to look into the factors that contributed into the celebration of such cross cultural and cross generic endeavours.

Translation Today Vol.10, Issue-I, June 2016 
Bengal Renaissance was a complex outcome of colonialism and the western education it brought along with it which not only transformed the consciousness of the social subjects but also created a rapid socio-political upheaval. The champions of Bengal renaissance had carefully sought a proper unification of the east and the west to consciously accomplish a complete regeneration of the contemporary society which was deeply immersed into stagnation, degradation and corruption. The death of Rammohun Roy, the renaissance champion in the year of 1833 in Bristol gave birth to a critical crisis in the face of the newly awakened Bengali intelligentsia. The immediate succession of his socio-cultural position should have fallen upon his Brahmo Samaj associates and the Young Bengal group, the dedicated followers of Derozio. However none of them could pertinently fill up the void created by his death. Despite several other prominent Brahmo leaders nobody could really live up to the level of expectation Roy had created. And unfortunately Derozio's early death in December 1831 had shaken the Young brigade to a great extent which had limited their further ambitions towards socio-political transformation and they were satisfied with repeating their past ways of radicalism in order to reconfirm their novelty in the face of the rigid social order censored by religion. The unavoidable void in due course of time gave birth to a series of socio-political disputes between the orthodox and the radicals but it was only in 1856, that Widow Remarriage became legal and the man who worked behind it was Ishwar Chandra Vidyasagar. The abolition of Sati in 1829 had stirred severe criticism and this too did not escape grave attacks from multiple social classes. Nevertheless Vidyasagar has been arduously identified as a vigorous social reformer and also as a great literary figure.

In the beginning of the $19^{\text {th }}$ century, there was a considerable shift in the Bengal intellectual circles. The rising 
middle class felt a need for acquiring a certain degree of English knowledge not just for working purposes but also because it provided them with a hefty sense of cultural upliftment. The foundation of the Fort William College in 1800 for the education of the British officials made it possible for the pundits to come in association with literary works of the masters and thus realize the possible existence of a different literature other than the ones they were versed in. An apparent synthesis of the east and the west must not undermine the colonial politics as seen in Macaulay's Education act of 1835 which was craftily presented to create a section of Brown Sahibs or assisting clerks to assist the British Empire in its functioning. To ensure such a development amongst the natives they had to be provided with an apparently thorough knowledge of the master's culture of which Shakespeare was an intrinsic part. It can be assumed as R.K Dasgupta proposes in his essay Shakespeare in Bengali Literature that, between the period of the establishment of the Hindu College in 1817 and 1835 when Bentinck approved Macaulay's Minute on English Education a considerable section of Bengali readers had already taken an initial interest in Shakespeare. Henry Louis Vivian Derozio who was appointed as a teacher in the Hindu College had contributed towards the radical fondness generated among the students about everything western. Captain D.L Richardson in this respect had been the most influential figure in the course of Shakespearean scholarship in Bengal. The appreciation of Shakespeare burgeoned after its initial welcoming on the stage. Since the foundation of the Calcutta Theatre in 1775, Bengal witnessed the rising section of "bhadraloks" accepting Shakespearean texts and recognizing their literary and cultural merit. Their identification soon gave way to multiple imitations or adaptations for the contemporary political scenario had psychologically moulded the Bengalis to project their local selves 
within the narratives of the Empire. Apparently it could be taken as an urge to portray characters with which the local people could identify themselves or relate to more easily and in the course have an idea about its Western writer for the benchmark of being a part of the intelligentsia was still the ones set by the boundaries of Western education. It resulted into the creation of a great number of indigenous literary works which quite potentially situated the Shakespearean texts into absolutely different socio-cultural contexts, at times remaining faithful to the main plot while at times going the other way.

One of such texts is Ishwar Chandra Vidyasagar's Bhranti Bilas (1869), which has a plot very close to that of Shakespeare's The Comedy of Errors and one might accurately consider it to be the first "translation" of Shakespeare into Bengali in the form of prose narrative. The second adaptation of the same text was created by Benimadhab Ghosh who named it as BhramaBilash (1873) was successfully staged. Vidyasagar's text finely deals with the plot keeping it almost the same but transforms its dramatic form into a story. Interestingly, this text was further adapted into a commercial film in 1963 directed by Manu Sen thus justifying the Bengali fascination for Shakespeare over the centuries. The plot of The Comedy of Errors had been craftily adapted by Shakespeare himself from the Latin comic master Plotus. Although Plotus had restricted the range of his plot between a single brethren of twins but the bard poet in order to increase the comic complexity had brought into the plot a second pair of twins. Ishwarchandra had however followed the plot composed by Shakespeare and other than the generic, dialogic and socio-cultural transformations did not make any serious alterations. As a direct result of such a complex characterization and plot, the play gives rise to a series of confusions thoroughly contributing to its comic essence. Ishwarchandra's selection of this 
particular Shakespearean text was probably due to the same reason. The comic essence had appealed to his literary sense strongly enough to provoke him to make a cross generic adaptation of it. Translation ventures gives in to the claim that a lot is lost in the process of translating but Ishwarchandra does by no means attempt to go for a direct translation but advances towards a new venture of positing the text in a different cultural range altogether. But in the advertisement that precedes the narrative of Bhrantibilash clearly addresses Shakespeare as the real master of literature recognized worldwide. He writes,

"A few days back I read Shakespeare's The Comedy of Errors after which I felt that it would be great to collect it in Bengali in order to cater to the taste of many people..."

His broadness and honesty lies in his prompt recognition of Shakespeare and his text as the original work of art and eventually justifying the further necessary adaptation of the text into the vernacular language. The comic tone of the play had appealed to the Bengali writer above all as he openly acknowledges the presence of real humour in the original text that should be widely spread to further appeal to the platters of the rising Bengali readers. It can therefore be deduced that unlike his other works such as Shankuntala or Sitar Banabas, Bhrantibilash had no social and moral educational or philosophical thoughts juxtaposed with literary crafts. Here it must be taken into account that this particular work of Vidyasagar very swiftly flits from any serious reflections at all compared to his other works. Even the reference to Shakespeare and his literary genius has been completed in a considerably short paragraph.

More than a work of translation Bhrantibilash is a free adaptation of The Comedy of Errors. While the former is a prose 
narrative, the latter is well recognized as a comic play. A thorough reading of both the texts instantly reveals that although the amount of addition to the original plot is negligible, there has taken place considerable amount of visible editing. Therefore the readers often come across additional elaborations giving in to the generic differences. Nevertheless, Vidyasagar has kept the descriptive passages short and simple only with minor exceptions. Rejections are a part of translation process and despite intensive efforts it is quite difficult to avoid them. The cultural alterations have also been done magnificently. Ishwarchandra never gives his readers the slightest opportunity to look back and compare his work with that of the original Shakespearean text. But the logic that he puts forward to justify his venture is not the final take on it. He stated that,

"In Bengali books, European names do not sound well."

What he does not reveal is his sincere intention to avoid the exposure of the fact that in his attempt of indianisation he had very smoothly rejected the English essence other than the structure and genre he spoke about. While the twin brothers Antipholus of Ephesus and Antipholus of Syracuse, sons of Egeon and Emilia becomes Chiranjib of Hemkuta and Chiranjib of Jayasthala, sons of Somdatta and the the priestess Labanyamoyee, Dromio of Syracus and Dromio of Ephesus becomes Kinkar of Jayasthala and Kinkar of Hemkuta serving their respective masters, Adriana and Luciana is transformed into Chandraprabha and Bilashini. Other than the geographical setting and indigenous construction of characters, certain other minor differences can also be located. However, if those differences are intentional or accidental is of course debatable. For instance, on entering the forbidden land of Ephesus, Solinus, the Duke of Ephesus penalizes Egeon to pay one thousand marks, where 
as all he can barely afford is a hundred marks,

"A thousand marks be levied,

To quit the penalty and to ransom him.

Thy substance, valued at the highest rate,

Cannot amount unto a hundred marks"

On the other hand in Bhrantibilash, Somdatta is asked to pay five thousand rupees and two hundred is all that he had. The value of the amounts clearly shows disparity hinting at the economic differences that probably existed between the two countries. A far sighted intellectual as he was, Ishwarchandra had a thorough knowledge of the socio-economic condition which prevailed in the society of nineteenth century Bengal. And probably this difference was intentionally reflected to throw light upon the existing reality in a harmless and witty manner. Similarly, Shakespeare had been satisfied with a single mast, accidentally separating the twins, as the text suggests,

"My wife, more careful for the latter-born, Had fasten'd him unto a small spare mast, Such as seafaring men provide for storms; To him one of the other twins was bound, Whilst I had been like heedful of the other: The children thus disposed, my wife and I, Fixing our eyes on whom our care was fix'd, Fasten'd ourselves at either end the mast:"

But the Bengali narrative had presented two masts contributing to the fatal separation caused by the natural calamity.

It was due to the factor of cross generic adaptation that Ishwarchandra had to change the language of the comic play into a language fulfilling the criteria of the colloquial Bengali language 
including idioms and curse. For instance, the conversation between Antipholus of Ephesus and Adriana and that of Chiranjib of Jayasthala and Chandraprabha bears almost no resemblance,

Antipholus of Ephesus: Are you there wife? You might have come before.

Adriana: Your wife, sir knave! go get you from the door.

In Bhrantibilash it has been written as,

"Hearing Chandraprabha's voice, Chiranjib of Jayasthala said, hey wife! What is the matter today? Listening to this, Chandraprabha fumed in rage and said, who the hell are you? Get lost from the door without disturbing, look at his audacity that he stands outside the door and calls me as his wife!"

Here the exaggeration must be excused for Ishwarchandra despite his free incorporation within the text by no means tampered with its essence. His intention had probably been to keep the literary essence of the Shakespearean text above anything else.

At one point there is a serious diversion from Shakespeare and that can be located in the characterisation of Chandraprabha aka Adriana and Bilashini aka Luciana. While Shakespeare had created a fiery tempered Adriana and sensitive and poetic Luciana, Ishwarchandra had portrayed Chandraprabha as over emotional and sensitive and Luciana as swift and smart although a certain degree of local colours has been put into their characterisations. At the time when Shakespeare had created such female characters, he was on his phase of creating type characters. It can be observed in The Taming of the Shrew how he creates Katherina Minola as the 'shrew' who is primarily indomitable in nature and then with the course of the play 
transforms into a docile creature. But in her former self she is quite a quarrelsome character whose temper is beyond any sort of control. Her sister Bianca on the other hand is much unlike her and there can almost be no comparison between the sisters in nature in the early half of the play. A conversation between Katherine and Petruchio reflects the tonal quality of Katherince much aptly where she powerfully shoves off Petruchio's claims of gentleness.

"Petruchio: Come, come, you wasp; i' faith, you are too angry.

Katherine: If I be waspish, best beware my sting.

Petruchio: My remedy is then, to pluck it out.

Katherine: Ay, if the fool could find where it lies.

Petruchio: Who knows not where a wasp does wear his sting?

In his tail.

Katherine: In his tongue.

Petruchio: Whose tongue?

Katherine: Yours, if you talk of tails: and so farewell.

Petruchio: What, with my tongue in your tail? Nay, come again,

Good Kate; I am a gentleman."

However, in The Comedy of Errors, Adriana if not as virulent as Katherine is also portrayed as a woman of high temper often giving in to domestic bickering is well known not only to her husband Antipholus, but also to his servant Dromio as we can see in the play,

Adriana: Go back again, thou slave, and fetch him home.

Dromio of Ephesus: Go back again, and be new beaten home?

For God's sake, send some other messenger.

Adriana:Back, slave, or I will break thy pate across.

But Ishwarchandra changes Adriana's heavy handed temper into an over sensitive and domestic house wife in Chandraprabha who is more anxious over losing her husband's affection above 
anything else and thus constantly needs Bilashini aka Luciana's emotional support.

However there are several other minor changes which can be located on further comparative analysis of the two plays. One must locate the literary position of Ishwarchandra amidst his sociocultural background. In The Wretched of the Earth, Franz Fanon articulates three phases through which an educated intellectual nationalist writer attains his consciousness. In the first phase, he adopts, that is he blindly imitates the master's texts. The second phase is to adapt, where he makes certain transformations or variations within the master's texts. And the third is adept, that is in this phase the gusto of his literary output emancipated from any other influence comes into being. Ishwarchandra's Bhrantibilash oscillates between the first and second phases for it takes a text intensely a part of a colonial culture and secondly he translates and transforms it freely with little inhibition on his authorial part. The social reformer and the ultimate renaissance icon Ishwarchandra should by no means be limited within any strict categorization of criticism but the possibility of acknowledging his venture of Shakespearean translation as advancement towards a new consciousness cannot be negated altogether.

\section{REFERENCES}

Bharucha, Rustom. 2004. "Foreign Asia/foreign Shakespeare: Dissenting Notes on New Asian Interculturality, Post-coloniality, and Recolonization". Theatre Journal 56.1: 1-28. Web.

Bhattacharyya, S. K.1964. "Shakespeare and Bengali Theatre". Indian Literature $7.1: 27-40$. Web.

Craig, W.J. ed. 1914. "The comedy of Errors." The Complete Works of William Shakespeare. London: Oxford University Press. 
The Comic Kaleidoscope: Untying the Comic Knots of Bhranti Bilas and the Comedy of Errors beyond Cultural and Generic Boundaries

DasGupta, R. K.1964. "Shakespeare in Bengali Literature". Indian Literature 7.1: 16-26. Web.

Murshid, Golam., ed. 1971. Vidyasagar. Kolkata: Bidyoday Library private. Ltd.

Siddiqui, Jillur Rahman.1971. “ Bhrantibilash.” Vidyasagar. Ed. Golam Murshid. Kolkata: Bidyoday Library, 61-72. 